\title{
Universalisme Islam Dan Kontribusinya Dalam Kronstruk Indonesia Baru
}

\section{Umi Sumbulab}

\section{I}

Indonesia baru, hingga detik inipun masih menjadi bahan perbincangan yang cukup menarik. Berbagai forum seminar dan dialog diselenggarakan dalam rangka mencari makna dan format ke depan sosok Indonesia baru tersebut. Berbagai tanggapan muncul dan berkembang, baik yang bernada optimistis bahwa Indonesia Baru akan benar-benar terciptakan, dın adapula yang bernada optimistis bahwa Indonesia Baru yang dicitakan banyak orang itu adalah angan-angan kcsong dan impian belaka.

Kedua kelompok tanggapan di atas -optimistis dan pesimistis- agaknya memiliki berbagai argumen pendukung. Kelompok pertama, menyatakan bahwa Indonesia baru akan benar-benar tercipta, dengan alasan : pertama, secara sosiologis, bangsa Indonesia memiliki potensi, yakni kemajemukan (pluralisme) tidak hanya pada teologi, tetapi juga institusi, organisasi, dan budaya. Disadari bahwa kemajemukan memang memiliki dua sisi, sisi konstruktif dan sisi destruktif. Sisi konstruktif itulah yang harus dikembangkan oleh bangsa tercinta ini. Kedua, kultur mondial yang tidak lagi terbatasi oleh geografi (trans-geografis) memberikan pengaruh yang sangat besar bagi berhembusnya demokratisasi. Karenanya, semua individu bangsa dapat "unjjuk gigi" menampilkan wajah demokratis, tentunya juga didukung dengan political will dari elite penguasa. Ketiga, meningkatnya kesadaran beragama. Hal ini, di antaranya dapat dilihat pada beberapa kaum agamawan yang tidak hanya memperhatikan aspek kesalehan ritual (statistikalnominal) tetapi juga aspek kesalehan aktual/sosial. Fenomena ini akan menjadi potensi konstruktif bagi penciptaan konstruk Indonesia baru.

Sementara kelompok yang bernada pesimistis dengan terciptanya Indonesia yang benar-benar baru, agaknya mendasarkan argumentasinya pada beberapa alasan pertama, trauma sejarah terporak-porandanya persatuan dan kesatuan bangsa oleh berbagai kepentingan; kedua, multi-krisis yang dialami Indonesia membuat bangsa ini sulit untuk membangun dan mengembalikan dalam waktu yang relatif singkat, sehingga Indonesia Baru juga kemungkinan besar sulit terciptakan.

Dalam kaitannya dengan konsep universalisme Islam clan konstribusinya dalam konstruk Indonesia Baru, dapat berangkat dari pemikiran tentang konsep aldharuriyat al-khamsah, yang tentu saja pemanahannya mencakup seluruh manusia dan perjalanan sejarah kemanusiaan Indonesia, yang dalam banyak hal bersifat diversity, sesuai dengan konsep rabmatan li al-'alamin.

\section{II}

Diskursus di seputar universalisme Islam, tidak terlepas dari konsep maqasbid al-syari'ah, yang familiar dengan sebutan dharuriyat al-kbamsah, yakni : 1) hak untuk hidup (bifdz al-bayat), 2) hak untuk mempertahankan keyakinan beragama (bifdzal-din), 3) hak untuk berfikir dan berpendapat (bifdz al-agl), 4) hak berketurunan (bifdz al-nasl).

Dalam kaitannya dengan dharuriyat al-kbamsab di atas, Islam sangat memberikan perhatian yang besar terhadap aktualisasinya. Karenanyà, Islam juga memberikan sekian aturan clan rambu-rambu serta petunjuk operasionalnya, kendati masih bersifat sangat umum. Justru dalam keumumannya inilah Islam menemukan elan vitalnya. Karena ia akan selalu dapat responsif dan dialogis terhadap perkembangan zaman. Di sinilah Islam dikenal sebagai agama yang memiliki keluasan dan keluwesan.

Upaya penegakan dlan penjagaan kelima hak dasar di atas, perlu dilakukan diantaranya dengan jałan secara terus menerus menyupayakan demokratisasi. Karena demokratisasilah jalan paling efektif terlaksananya dan terlindunginya hak-hak dasar di atas (HAM).

Terdapat tiga elemen penting dalam perwujudan demokratisassi ini, yakni justice, equality dan freedom 
(Khofifah, 1999). Justice (keadilan) harus dapat dinikmati dan dirasakan setiap manusia dari kalangan manapun, tidak seperti dalam praktik selama ini bahwa keadilan hanya milik kaum borjuis dan tidak berpihak pada kaum ploretar. Hal ini, sebenarnya sudah diprediksikan oleh Rasulullah dalam salah satu teks hadisnya yang intinya bahwa "kehancuran generasi sebelum kita adalah karena mereka tidak menjunjung tinggi prinsip keadilan, yakni ketika pencurian (kedzaliman) dilakukan oleh kalangan bangsawan maka tidak ditegakkan hukum kepadanya sementara jika yang melakukan pencurian (kedzaliman) itu adalah kalangan kaum dhu'afa' maka ditegakkan hukum padanya". Karenanya, jika bangsa Indonesia ingin bisa survive, maka juga harus menjunjung tinggi nilai keadilan (justice) dan persamaan equality) ini, yang meliputi ekonomi (properti dan kesempatan kerja) serta keadilan dalam perlakuan dan perlindungan hukum.

Islam dengan prinsip universalismenya, sangat memperhatikan keadilan dalam berbagai bidang, tersebut di atas. Karenanya, tegaknya keadilan merupakan cita-cita yang harus direalisasikan dalam setiap kesempatan. Sinyalemen al-Qur'an tentang terma-terma keadilan yang dicerminkan dalam beberapa ayatnya, memberikan pemahaman bahwa pesan moral ini harus selalu ditegakkan. Ini bisa dilihat misalnya dalam QS

Menegakkan keadilan dalam bidang apapun, merupakan segmentasi dari hakikat dasar kemanusiaan. Ia juga merupakan sunnatullah, yang inheren dengan eksistensi kelahiran manusia di dunia fana ini. Untuk itu, keharusan menegakkan keadilan merupakan keharusan zaman yarig bernilai hukum yang obyektif (Nurcholis, 1995: 184). Al-Qur'an bahkan menyatakan bahwa keadilan merupakan bagian dari liukum kosmis yang harus dijaga keseimbangannya secara mutlak. Karena jika tidak, akan menimbulkan kekacauan. Penegakan keadilanakan menciptakan kebaikan, terlepas dari siapapun yang melaksanakannya: Sebaliknya ketiadaan upaya penegakan keadilan akan menga- kibatkan malapetaka, tanpa memandang siapapun yang melakukannya.

Agaknya, pesan moral penegakan keadilan ini memang mendapatkan prioritas. Inị bisa terlihat dari penghargaan Tuhan terhadap keadilan karena ia dianggap sebagai karya positif yang paling dekat.dengan ketakwaan -satu standard penghargaan tertinggi yang dapat membedakan kedudukan masing-masing individu di hadapan kebesaran Tuhan.

Pesan Tuhan tentang penegakan keadilan ini, juga menjadi perhatian khusus nabi, ketika menjelang kewafatan beliau, dengan teks sebagai berikut :

"Wahai sekalian manusia! Ingatlah Allah! Ingatlah Allah, dalam agamamu dan sekalian: Ingatlah Allah ! Allah, berkenaan dengan yang kamukuasaidengan tangan nanmu! Berilah mereka makan yang kamu makan, dan mereka pakaian seperti yang kenakan! Dan janganlah kamu bani mereka dengan beban mereka tidak sanggup menanggungnya. Sebab sesungguhnya mereka adalah daging, darah dan makhluk seperti halnya kamu sekalian' sendiri. Awas, barangsiapa bertindak dzalim kepada mereka, maka akulah musuhnya di Hari Kiamat, dan Allah adalah hakimnya.........". (Nurcholis Madjid, 1995 ; 185).

Dari pidato Rasulullah di atas, dapat dipahami betapa tingginya tingkat kemendesakan nilai keadilan harus diaktualisasikan dalam kehidupan ini. Bahkan saking tingginya nilai keadilan ini, Rasülullah mengancam orang yang tidak mau menegakkannya (dzalim) dengan ancaman bahwa orang tersebut akan menjadi musuh Rasulullah dan akan dihakimi sendiriloleh Tuhan.

Berangkat dari sinyalemen teọlogis clan realitas historis di atas, maka sudah nienjadi keharusan setiap manusia untuk menegakkari keadilan, di antaranya dengan memiliki sikap keberpihakan pada kaum dbu'afa' dàn mustadb'afin, baik dalam distribussi ekonomi, pendidikan, hukum, politik dan semua hak dasar kemanusiaan.

Kembali kepada masalah universalisme İslam, di 
samping terlihat dalam konsep al-sharuriyat alkhamsab, juga terlihat dalam aspek kesejarahan maupun substansi Islam itu sendiri.

Secara kesejarahan, Islam khusus (institusi formal) yang dibawa oleh Rasulullah Muhammad merupakan kelanjutan dan konsistensi serta keterpautan historis dengan ajaran keagamaan yang dibawa oleh nabi-nabi terdahulu, di mana inti pesan-pesan keagamaan dimaksud adalah tawhid. Keterpautan historis antara Islam yang dibawa Muhammad dengan Islam yang dibawa oleh nabi-nabi terdahulu adalah : pertama, adanya kesamaan geografis, yakni hampir seluruh nabi diutus di kawasan jazirah arab. Ini menandakan bahwa bangsa Arab merupakan representasi dekadensi moral norma kehidupan dunia dalam setiap kurun diutusnya para nabi. ,Kedua, masih banyaknya syariat nabi-nabi terdahulu yang tidak diabrogasi dengan kehadiran Islam yang dibawa Muhammad Saw. dan bahkan tetap dilaksanakan hingga sekarang.

Keterpautan sejarah antara nabi itu menunjukkan bahwa sebenarnya inti dari missi profetik para utusan Tuhan itu adalah Islam, yakni sikap kepasrahan dan ketundukan total hamba kepada Tuhannya. Karena itu pulalah, agaknya al-Qur'an menyitir bahwa : Bukankah Ibrahim itu seorang Yahudi dan bukan pula seorang Nasrani, akan tetapi dia adalah seorang muslim yang banif (QS. 3:67).

Ayat di atas memperkuat tesis bahwwa yang dibawa oleh semua nabi itu ticlak tereduksi dengan nama primordialisme yang mengacu kepada istitusi formal semisal Islam, Nasrani, Yahudi clan lain-lain, tetapi lebih kepada aktualisasi nilai profetik dalam bentuk kepatuhan dan ketundukan makhluk terhadap sang Khalik, kendati betapa ada perbedaan dalam clataran eksoteris masingmasing.

Penyebutan al-Qur'an bahwa Ibrahim bukanlah seorang Yahudi dan juga bukan seorang Nasrani, didasarkan pacla alasan : pertama, karena secara historis kemunculan dan kepengutusan Ibrahim adalah jauh sebelum munculnya ajaran nabi Musa —yang kemudian diidentifikasikan sebagai agama etnis Yahudi- dan ajaran Isa —yang pada tahab berikutnya dinisbatkan kepada suatu tempat diutusnya nabi Isa yakni di Nazareth, sehingga kemudian pesan keagamaan yang clibawanya dinamakan Nasrani. Kedua, karena Ibrahim hanya mengikutikebenaran primordial — perennial yang inheren dengan eksistensi manusia di dunia ini (fitrah). Pesan ajaran Ibrahim ini, pada tahap berikutnya diikuti oleh Musa, Isa dan Muhammad sendiri. Karenanya, agama (institusional-formal) yang clisandarkan kepada ketiga nabiyullah ini disebut sebagai the Abrabamic Religions (agama satu rumpun dari kakek Ibrahim). Karena satu rumpun, sebagai konsekuensinya tidak mungkin substansi ketiganya berbeda.

Berpijak pada statemen di atas, clapat dipahami bahwa missi profetik pembawa agama Ibrahim adalah satu, yakni tawhid, yang diimplementasikan pada bentuk kepatuhan dan ketundukan kepada Tuhan. Karenanya, trutb claim, superiorits inferioritas satu atas yang lain tidak layak dimunculkan. Hal ini penting dilakukan dalam menjaga hak keagamaan (bifz al-din) setiap individu dalam rangka terciptanya tatanan Indonesia Baru yang diimpikan semua komponen bangsa, seehingga terhindar dari segala macam clash dan konflik serta kemungkinan penciptaan zona yang dapat "diobok-obok" oleh kepentingan-kepentingan tertentu.

Dalam doktrin religi, independensi terlihat pacla konsep tawhid, yakni pembebasan cliri dari segala bentuk ketergantungan dan penghambaan diri kepada selain Tuhan (QS. 16:36). Tuntutan bersikap demikian tercemin dalam ikrar syabadat yang menuntut ketiadaan sekutu atau penyetaraan terhadap Allah. Terma lailaba... (tiada Tuhan) mengandung arti semua sistem kepercayaan palsu yang akan menetralisir rohani dari pemujaan yang keliru. Baru kemudian diikuti statemen affirmatif berupa pengakuan akan eksistensi Tuhan Yang Maha Kuasa, dengan terma illa Allab (kecuali Allah).

Pembebasan diri clari segala bentuk ketergantungan dan penghambaan terhadap selain Tuhan inilah sebenarnya intisari risalah semua kenabian yang diutus Tuhan untuk semua bangsa di muka bumi ini.

Pendapat beberapa sinyalemeri al-Qur'an tentang kecenderungan manusia untuk berlaku tiran, yakni ketika seseeorang merasa bahwa dirinya berkecukupan (istaghna) (QS. 20:24). Sikap seperti ini pada tahap berikutnya akan menghilangkan dan menumpulkan kepekaan clan komitmen sosial seseorang. Selanjutnya juga berimplikasi pada pengikisan hak-hak dasar 
kemanusiaan, satu sikap yang sangat bertentangan dengan prasyarat penciptaan Indonesia baru yang ideal. Ini karena bersikap kurang membutuhkan orang lain, berarti meremehkan mereka dan menganggap dirinya superior, satu sikap pemaksaan pengakuan orang lain terhadap dirinya. Hal ini juga bertentangan dengan konsep tawhid yang dalam cakupan lebih luas dapat menumbuhkan komitmen sosial yang membawa kepada pembebasan manusia dari segala bentuk ketergantungan (non-independence) dan penghambaan terhadap selain Tuhan.

Lebih jauh, kepasrahan total terhadap Tuhan ini akan memacu semangat dan aktivitas positif bagi manusia. Hal ini. perrnah ditunjukkan kepada dunia oleh masyarakat di awal-awal Islam, dengan keyakinan dan kepercayaan penuh mereka membebaskan diri dari "cengkeraman" kekuatan bangsabangsa sekitarnya. Bahkan dalam perkembangan selanjutnya, umat Islam disambut kedatangannya sebagai "pembebas" dari berbagai negara yang dijajah oleh rezim Romawi, Byzantium yakni Irak, disusul

Dengan mengamati prilaku
manusia dalam mengikuti perintah
dan menjauhil larangan Tuhan akan
memberikan pengertian bahwa
manusia itu, adalah makhluk
budaya. Karena dibentuk dan
berkembang menjadi seorang yang
berkepribadian terjadi dalam
kebudayaan masyarakat. Di
masyarakat nilai-nilai etis manusia
adalah menjadi dasar dan.
ukurannya yang merupakan sumber
orientasinorma-norma masyarakat.

manya" (HR. al-Bukhari).

Teks hadis diatas, memiliki kandungan makna yang sangat luas. Keluasan dimaksud teerdapat dalam dua hal : pertama, seseorang dapat memberikan dampak positif pada sesamanya jika ia sendiri memiliki (sejumlah) kepositifan; kedua, terma "memberikan kepositifan kepada sesama" memiliki cakupan makna yang luas, yakni bisa berarti keluarga, masyarakat dan bangsanya. Karenanya, seseorang yang mendapat predikat insan terbaik, adalah insan / setiap individu yang memiliki kepedulian terhadap diri, keluarga, masyarakat dan bangsanya.

Kepedulian terhadap diri sendiri ditandai dengan adanya pemahaman seseorang akan potensi diri, bakat, kelebihan dan kekurangannya. Di sinilah setiap individu dituntut untuk mengoptimalisasikan potensi dan menggali kelebihan serta menutupi kekurangan dirinya. Jika setiap individu memiliki kepedulian akan dirinya maka dia akan memiliki kepedulian terhadap sesamanya.

Kepedulian terhadap keluarga, dipahami sebagai kepedulian terhadap segala hal yang menimpa, menjadi beban dan tanggung jawab keluarganya. Ini diisyaratkan pula oleh QS. 66:6. Kepedulian jenis ini membawa konsekuensi logis pada keharusan bagi orang tua untuk memberikan pendidikan dan bimbingan yang terbaik kepada anggota keluarganya (dalam hal ini anak-anaknya/pihak-pihak yang menjadi tanggungannya).

Kepedulian terhadap masyarakat dipahami bahwa untuk menciptakan keharmonisan hidup, setiap individu harus menyadari hak dan kewajibannya, sesuai dengan kodrat manusia sebagai makhluk individual dan makhluk sosial sekaligus. Karena itu segala hal yang berkaitan dengan orang lain terutama masalah yang menyangkut orang banyak, setiap individu harus mempunyai rasa inemiliki (sense of belonging). Sehingga ia satu dengan yang lain benar-benar merasa bersaudara (QS. 49:10).

Kepedulian terhadap bangsa membawa implikasi 
pemikiran bahwa setiap individu harus memiliki rasa tanggung jawab terhadap segala hal yang dialami bangsanya, maju dan mundurnya bangsa dan lain-lain. Karenanya, logis kalau kemudian para pemikir dan pembela nasionalisme, sampai-sampai mengkaitkan antara kepedulian terhadap bangsa ini sebagai bagian dari elemen penyempurna tingkat keimanan seseorang (bubb alwatbain min al-iman).

Kepedulian terhadap keempat unsur di atas, dituntut dalam upaya menata Indonesia'Baru. Ini karena Indonesia baru mengharuskan keteerlibatan dan partisipasi aktif dari seluruh komponen bangsa, sesuai dengan posisi dan proporsinya. Di sinilah agaknya letak independensi (kemandirian) itu diarahkan.

Universalisme Islam, di samping terlihat pada adanya independensi dan demokratisasi, juga dapat disimak pada ajaran-ajarannya yang memiliki kepedulian terhadap unsur-unsur utama kemanusiaan, yang diimbangi oleh kearifan yang muncul dari watak peradaban Islam itu sendiri yang terbuka, adaptif dan akomodatif (Abdurrahman Wahid, 1995:545).

Dalam spektrum yang lebih luas, kemandirian (independensi) harus dapat dimiliki oleh negara kendati dalam kultur global. Artinya, bahwa di era keterbukaan di segala lini kehidupan ini, setiap bangsa dituntut untuk mampu mandiri dengan tujuan agar tidak terlindas dan tidak pula terbawa arus kemodernan, tetapi dapat beradaptasi di dalamnya dengan tidak kehilangan jati dirinya sebagai sebuah bangssa, yang memiliki ciri khas keadaban tersendiri.

Permasalahannya adalah,' di mana Islam dapat membuktikan universalitasnya terutama di era Indonesia baru yang dicitakan seluruh komponen masyarakat Indonesia? pertanyaan tersebut tidak mudah ditemukan jawaban dan solusinya. Mengapa, karena di samping pemahaman umat Islam sendiri terhadap Islam belum sepenuhnyaberkeadilan dan memperhatikan komponen di luar komunitas muslim, juga karena belum adanya pemahaman yang komprehensif dan integratif terhadap Islam itu sendiri.

Kontribusi Islam dalam menciptakan konstruk Indonesia Baru juga harus dipahami seberapa jauh potensi yang telah diisyaratkan Islam itu ditangkap maknanya, sehingga bisa diaktualisasikan seiring dengan proses Indonesia Baru itu sendiri tercipta.

\section{III}

Indonesia Baru merupakan satu cita ideal yang memiliki kemungkinan besar tercipta. Ini karena bangsa Indonesia memiliki potensi untuk mewujudkannya. Secara sosiologis, keragaman yang dimiliki bangsa tercinta ini dapat menjadi potensi konstruktif bagi penciptaan cita ideal dimaksud. Cita rasa agamis, juga merupakan potensi lain yang bisa dikembangkan, karena nilai-nilai keagamaan universal dapat mewarnai segala aspek kehidupan bangsa ini, baik menyangkut kehidupan sosial, budaya, hukum, politik maupun lainnya.

Universalisme Islam, dengan konsep al-dharuriyat al-kbamsab-nya, merupakan penopang bagi tegaknya hak asasi manusia (HAM), yang terderivasi pada lima hak dasar kemanusiaan, yani meliputi hak hidup (bifz al-bayat), hak kepemilikan atas harta/properti (bifz almal), hak mempertahankan keyakinan agama (bifz aldin), hak untuk berfikir dan berpendapat (bifz al-'agl) dan hak berketurunan (bifz al-nasl).

Dalam rangka menjamin terpeliharanya kelima hak dasar di atas, setiap komponen bangsa diharuskan memiliki prasyarat berupa independensi dan demokratisasi yang meliputi freedom, justice dan equality. Prasyarat dimaksud, menuntut implementasi tidak hanya oleh masyarakat tetapi juga good will and political will dari elite penguasa. Semoga, teraktualisasikannya nilai-nilai universalisme Islam dalam rangka menuju Indonesia Baru bukan hanya kamuflase akademik belaka.

\section{Daftar Pustaka}

1. Abdurrahman Wahid, Universalisme Islam, dalam Buddy Munawar-Wahman (Editor), Kontekstıalisasi Doktrin Islam dalam Sejarab Paramadina, Jakarta, 1995

2. Alwi Shihab, Islam Inklusif, Mizan, Bandung, 1998.

3. Harun Nasution, Kuliab Sejarab Peradaban Islam, PPS IAIN "Imam Bonjol" Paclang 1995.

4. Khofifah Indar Parawansa, Perbincangan di Seputar Indonesia Baru, Radio Kalimaya Baskara, September 1999

5. Nurcholis Madjicl, Islam Agama Kemanusiaan, Paramadina, Jakarta, 1995

6. George B. Grose clan Benjamin J. Hubbard (Ed.), Tiga Agama Satu Tuban: Sebuab Dialog, Mizan, Bandung, 1998. 